\title{
PENENTUAN SPHERICITY DAN DISTRIBUSI INTENSITAS BERKAS ELEKTRON DARI SUMBER ELEKTRON TIPE PIERCE BERBASIS MATLAB
}

\author{
Achmad Ramadhani ${ }^{1}$, Darsono ${ }^{2}$, Anwar Budianto ${ }^{3}$, Suhartono ${ }^{4}$ \\ 1) STTN-BATAN, Yogyakarta, Indonesia, achmad.ramadhani@gmail.com \\ 2) PSTA-BATAN, Yogyakarta, Indonesia, b_darsono@batan.go.id \\ 3) STTN-BATAN,Yogyakarta, Indonesia, taufad@yahoo.com \\ 4) PSTA-BATAN, Yogyakarta, Indonesia, suhartono@gmail.com
}

\begin{abstract}
ABSTRAK
PENENTUAN SPHERICITY DAN DISTRIBUSI INTENSITAS BERKAS ELEKTRON DARI SUMBER ELEKTRON TIPE PIERCE BERBASIS MATLAB. Telah dilakukan penentuan bentuk profil berkas elektron dari sumber elektron tipe Pierce berbasis GUI MATLAB dengan empat tahapan submenu aplikasi, yaitu capture video, preprocessing citra, segmentasi citra, dan penentuan profil berkas elektron. Pembuatan aplikasi digunakan untuk karakterisasi sumber elektron (dioda dan trioda) dari hasil nilai sphericity, dan plot distribusi intensitas berkas elektron dengan perubahan pengaturan parameter tegangan pemercepat, dan tegangan pemfokus pada arus tetap. Hasil pengujian memperlihatkan bahwa sumber elektron tipe Pierce pada trioda memberikan bentuk profil berkas elektron lebih baik dibandingkan dengan sumber elektron dioda dengan nilai sphericity semakin mendekati 1 dan nilai rata-rata distibusi intensitas yang lebih merata secara kuantitatif atau dari hasil visualisasi plot grafik 3D.
\end{abstract}

Kata Kunci: dioda, distribusi intensitas, MATLAB, sphericity, dan trioda

\begin{abstract}
DETERMINATION OF SPHERICITY AND ELECTRON BEAM INTENSITY DISTRIBUTION FROM PIERCE-TYPE ELECTRON SOURCE BASED ON MATLAB. Determination of the profile shape of electron beam from Pierce-type electron source has been conducted based on MATLAB GUI with four stages of application submenus, i.e. video capture, image preprocessing, image segmentation, and the determination of the electron beam profile. Creation of applications used to characterization of electron source (diode and triode) from the value of sphericity, and electron beam intensity distribution plot with variation of accelerating voltage and focussing voltage parameter when current constant. The test results showed that Pierce-type electron source of triode gave electron beam profile with better shape compared to electron source of diode with sphericity value close to 1 and average value of intensity distribution is more even by either quantitatively or with visualitation from $3 D$ graph plot.
\end{abstract}

Keywords: diode, MATLAB, intensity distribution, sphericity, and triode 


\section{PENDAHULUAN}

Salah satu bagian penting dari Mesin Berkas Elektron (MBE) adalah sumber elektron (SE) yang berfungsi sebagai penghasil berkas elektron yang akan diradiasikan pada suatu bahan. Karakteristik luaran berkas elektron tidak hanya ditentukan oleh parameter energi kinetik yang berpengaruh terhadap tingkat kedalaman penembusan (penetration depth) tetapi parameter profil berkas serta intensitas juga sangat berpengaruh terhadap kualitas luaran berkas elektron yang akan diradiasikan pada suatu bahan.

Pada tahun 2014, PSTA-BATAN telah berhasil mengkonstruksi modul SE 3 elektroda yang didesain berdasarkan elektroda katoda tipe Pierce [1]. Tujuannya adalah dihasilkan berkas elektron yang mempunyai kualitas lebih baik, yaitu berkas elektron terfokus dibandingkan dengan konstruksi modul SE dioda [2].

Keterbatasan pengukuran profil berkas elektron dengan metode kertas kalkir [3], foil alumunium, dan rotating probe [4], adalah pengukuran profil berkas di atas tidak dapat memberikan informasi pengukuran secara kuantitatif hanya berdasarkan pengamatan secara visual dan tidak dapat menampilkan informasi bentuk profil secara langsung. Oleh karena itu, dilakukan perancangan pengukuran profil berkas elektron dengan metode tabung sinar katoda (cathode ray tube atau CRT) berbasis pengolahan citra digital dengan software MATLAB. Hasil pendaran cahaya tampak yang muncul pada layar TV selanjutnya ditangkap dan direkam menggunakan kamera CCTV yang terhubung ke laptop atau komputer melalui perangkat video adaptor dengan koneksi USB 2.0. Tangkapan gambar berkas elektron dari kamera CCTV selanjutnya ditampilkan secara langsung pada laptop atau komputer dengan memanfaatkan fasilitas tool GUI dari progam MATLAB seri R2013a. Progam MATLAB selanjutnya mengolah data citra analog dari tangkapan profil berkas elektron untuk dikonversi menjadi citra digital dalam bentuk matriks dua dimensi. Teknik pengolahan citra digital selanjutnya dilakukan untuk mendapatkan informasi bentuk beam profile dan distribusi nilai intensitas yang terukur dalam tingkat derajat keabuan sebagai representasi dari cahaya tampak yang terdistribusi pada layar tabung CRT. Idealnya hasil dari luaran profil berkas adalah berbentuk geometri bundar dengan distribusi intensitas memuncak di tengah, layaknya kurva Gaussian. Pemilihan perangkat layar tabung $C R T$ sebagai penampil citra berkas elektron dan kamera jenis CCTV sebagai penangkap citra digital tiga dimensi (video) dilakukan dengan pertimbangan harganya murah dan mudah didapatkan di pasaran.

\section{LANDASAN TEORI}

\section{Sumber Elektron Tipe Pierce}

Susunan elektroda Pierce telah dikenal sebagai suatu susunan elektroda yang dapat membentuk berkas elektron yang lurus atau hampir tidak menyebar dengan kerapatan yang cukup tinggi. Susunan elektroda tersebut terdiri dari katoda yang berfungsi untuk mendorong elektron dari daerah filamen, dan anoda yang berfungsi sebagai celah untuk mengekstraksi elektron dari dalam sumber elektron. Skema sumber elektron tipe Pierce untuk dioda dan trioda ditunjukkan pada Gambar 1. Pada SE tipe Pierce dioda, anoda ekstraksi ( $\mathrm{Va}$ ) terletak pada elektroda pemercepat $(\mathrm{Vp})$ yang berdekatan dengan katoda filamen $\left(\mathrm{V}_{\mathrm{k}}\right)$. Adapun pada SE tipe Pierce trioda, elektroda ketiga, yaitu pemfokus(Vf), diletakkan di antara Vk dan Vp yang berfungsi untuk mengatur bentuk berkas elektron yang akan dipercepat.

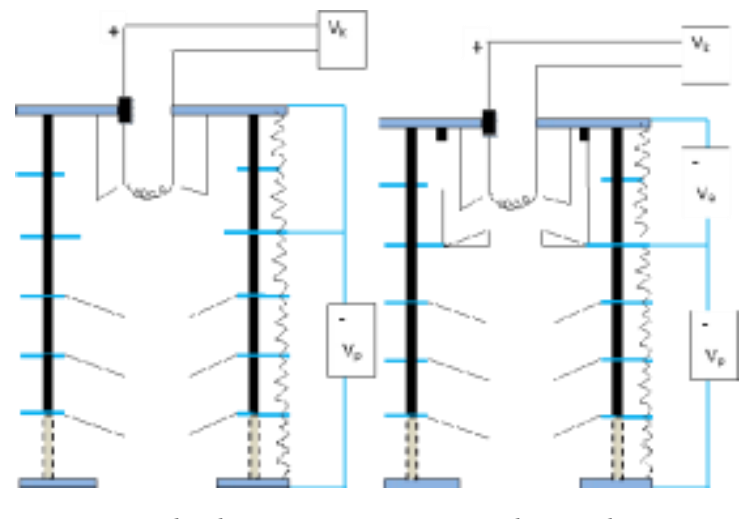

a. dioda

b. trioda

Gambar 1. Sumber Elektron Tipe Pierce

\section{Parameter Luaran Berkas Elektron}

Parameter utama luaran berkas elektron [6], yaitu: 


\section{Arus Berkas}

Parameter yang menentukan arus berkas elektron terkait tipe atau jenis sumber elektron, di antaranya meliputi arus filamen dan tegangan ekstraktor sedangkan yang terkait dengan pembentuk sumber ion elektron, meliputi tegangan ekstraktor, tegangan pemfokus, dan tegangan pemercepat.

Energi Berkas. Besarnya energi elektron diperoleh dari tegangan pemercepat yang terpasang pada tabung pemercepat.

Profil Berkas. Profil berkas idealnya berbentuk bundar dan homogen, di mana distribusi intensitas merata berbentuk Gaussian plot.

\section{Tabung Sinar Katoda}

Bahan layar di bagian dalam CRT yang menghasilkan efek ini adalah fosfor. Fosfor menyerap energi kinetik elektron-elektron pembombardir dan memancarkan kembali energi tersebut pada frekuensi yang lebih rendah dalam spektrum yang dapat dilihat sebagai bentuk visualisasi dari berkas elektron yang dipancarkan dari sumber elektron pada layar tabung CRT. Sifat dari beberapa bahan berkristal seperti fosfor atau oksida seng yang memancarkan cahaya bila dirangsang oleh radiasi disebut fluoresensi.

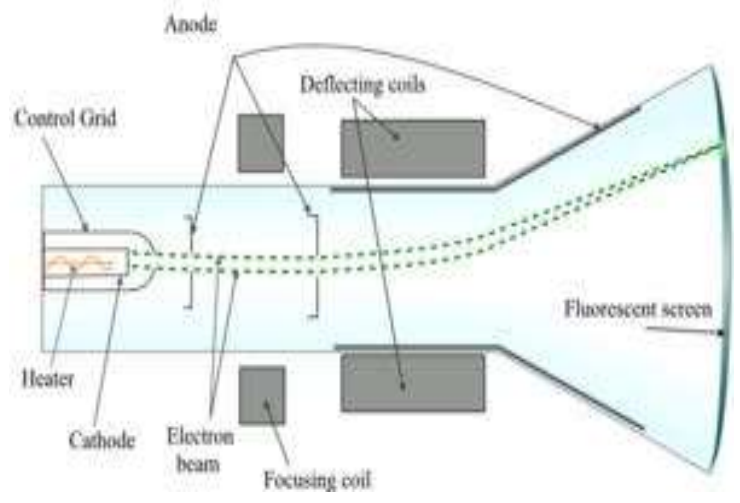

Gambar 2. Skema Tabung Sinar Katoda [7]

\section{Kamera CCTV}

Closed Circuit Television (CCTV) merupakan sistem kamera video digital untuk menggambil gambar atau video yang kemudian ditransmisikan ke penerima tertentu dan ditampilkan dalam seperangkat monitor, sebagaimana ditunjukkan pada Gambar 3. Komponen kamera akan menangkap objek gambar yang akan ditransformasikan menjadi sinyal-sinyal elektronik, dan selanjutnya sinyal-sinyal tersebut akan dikonversikan dari format analog ke format digital dan ditransfer melalui sebuah komputer.

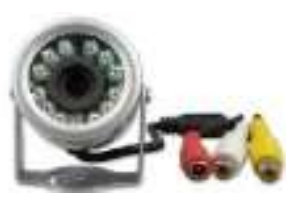

Gambar 3. Kamera CCTV

\section{Program MATLAB}

MATLAB adalah sebuah bahasa dengan kinerja tinggi (high-performance) untuk komputasi masalah teknik. MATLAB mengintegrasikan komputasi, visualisasi, dan pemrograman dalam suatu model yang sangat mudah untuk dipakai, di mana masalahmasalah dan penyelesaiannya diekspresikan dalam notasi matematika yang familiar[8].

\section{Pengolahan Citra}

Pengolahan citra mencakup enam jenis operasi pengolahan [9]:

1. Peningkatan kualitas citra (image enhancement). Jenis operasi ini bertujuan untuk memperbaiki kualitas citra dengan cara memanipulasi parameter-parameter citra.

2. Restorasi citra (image restoration). Operasi ini bertujuan untuk memperbaiki kualitas citra.

3. Kompresi citra (image compression). Jenis operasi ini dilakukan agar citra dapat direpresentasikan dalam bentuk yang lebih kompak sehingga memerlukan memori yang lebih sedikit.

4. Segmentasi citra (image segmentation). Operasi ini adalah suatu tahap pada proses analisis citra yang bertujuan untuk memperoleh informasi yang ada dalam citra tersebut

5. Analisis citra (image analysis). Jenis operasi ini bertujuan menghitung besaran kuantitatif dari citra untuk menghasilkan deskripsinya.

6. Rekonstruksi citra (image reconstruction). Jenis operasi ini bertujuan untuk membentuk ulang objek beberapa citra hasil proyeksi. 


\section{MMO (Metric Mutual Overlap)}

Pendekatan Mutual Overlap juga dikenal sebagai istilah evaluasi Dice. Prinsip kerja teknik MMO (Metric Mutual Overlap) berdasarkan teknik komputasi irisan (tumpang tindih) area antara citra ground truth dan citra dengan region yang telah tersegmentasi. MMO dapat didefinisikan dengan persamaan:

$$
M_{M O}=\frac{2 M O}{A_{1}+A_{2}}
$$

di mana area yang dinormalisasi adalah total area antara dua region, yaitu area yang telah tersegmentasi $\left(\mathrm{A}_{1}\right)$, area ground truth $\left(\mathrm{A}_{2}\right)$ dan MO adalah area irisan antara $A_{1}$ dan $A_{2}$. Ilustrasi MMO ditunjukkan pada Gambar 4.

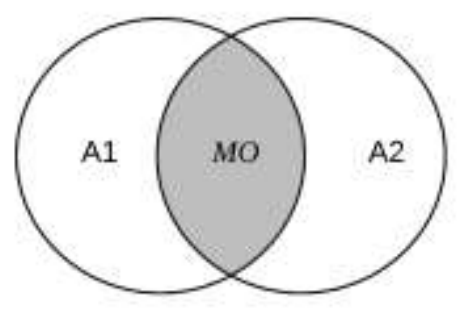

Gambar 4. Ilustrasi MMO

(Metric Mutual Overlap) [10]

\section{Sphericity}

Sphericity adalah ukuran yang menunjukkan kebulatan suatu objek. Menurut Wadell (1935), sphericity dari suatu partikel adalah rasio dari luas permukaan suatu bola yang mempunyai volume yang sama dengan partikel tersebut dengan luas permukaan partikel [11]. Jika nilai sphericity suatu benda semakin mendekati satu ( 1), maka benda tersebut semakin menyerupai bola. Ada beberapa metode yang digunakan untuk menentukan sphericity citra dalam bentuk dua dimensi (2D), yaitu di antaranya dengan membandingkan diameter terpendek $\left(D_{\min }\right)$ dan diameter terpanjang $\left(D_{\max }\right)$, membandingkan area dengan rumus $\pi \mathrm{r}^{2}$, membandingkan perimeter dengan persamaan $\pi \mathrm{r}^{2}$, menghitung dengan persamaan modifikasi Krumbein, dan menghitung nilai eccentricity.

\section{Plot Distribusi Normal}

Distribusi probabilitas normal adalah distribusi probabilitas dari variabel acak kontinu yang simetris dan mesokurtik. Kurva yang dihasilkan berbentuk lonceng yang simetris kiri dan kanan. Distribusi normal ini disebut juga sebagai distribusi Gauss, di mana model noise Gaussian tersebar dalam distribusi normal ini. Dua parameter yang menentukan kurva distribusi normal adalah rata-rata (mean) dan simpangan baku (standar deviasi). Fungsi yang digunakan untuk membuat sebuah grafik 3D adalah plot. Fungsi ini memiliki bentuk berbeda, bergantung pada argumen input yang diberikan. Sintaks yang digunakan untuk menampilkan argumen input koordinat $\mathrm{x}, \mathrm{y}$, dan $\mathrm{z}$ adalah surf.

\section{METODE PENELITIAN}

\section{Alat dan Bahan}

Dalam penelitian ini dibutuhkan beberapa alat dan bahan, yaitu:

1. perangkat pengujian modul sumber elektron profil berkas elektron: sumber DC tegangan tinggi, sumber elektron Pierce (dioda dan trioda), tabung pemercepat, pompa vakum, tabung sinar katode $(C R T)$;

2. perangkat pengolah citra profil berkas elektron: kamera CCTV, video adaptor USB.2.0, kabel USB- coaxial, laptop;

3. software pengolah citra digital: sistem operasi Windows XP, MATLAB R2013a, Paint;

4. perangkat pengukur intensitas cahaya: Lux Meter.

\section{Metode Penelitian}

Langkah penelitian ditunjukkan pada Gambar 5 sebagai berikut: 


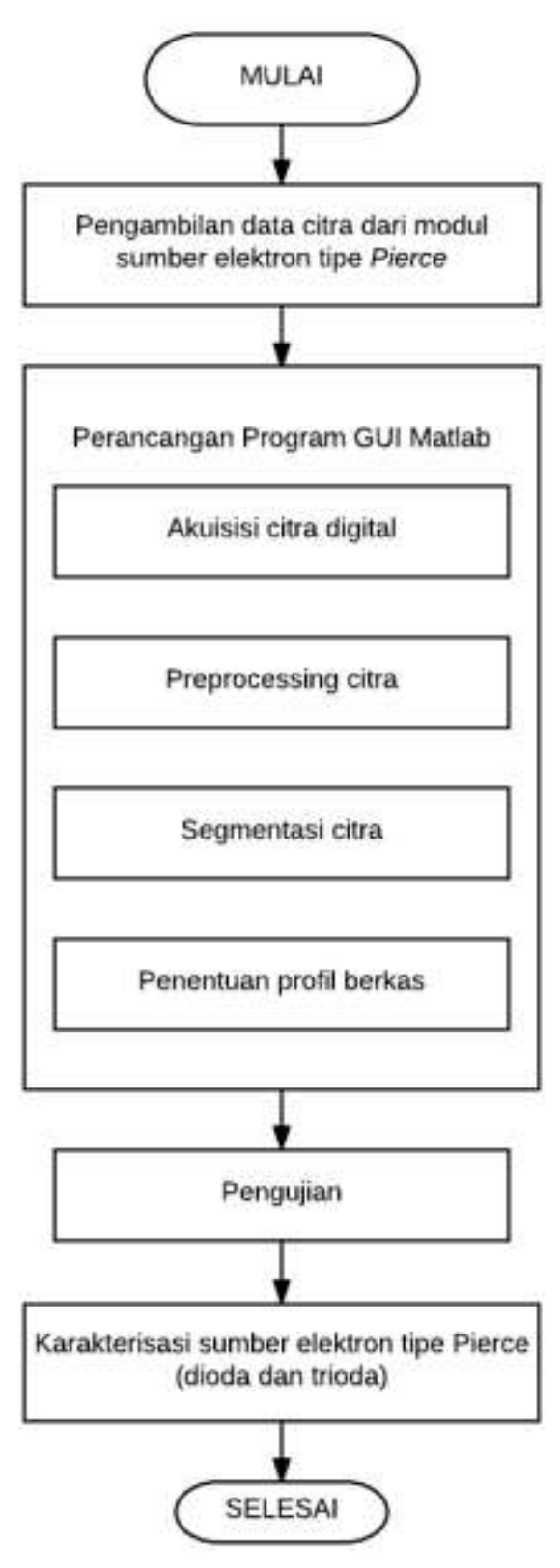

Gambar 5. Diagram Alir Penelitian

\section{Pengambilan Data Citra dari Modul SE}

Pengambilan data citra dari modul sumber elektron dapat ditunjukkan pada skema modul konstruksi pengukuran profil berkas elektron pada Gambar 6.
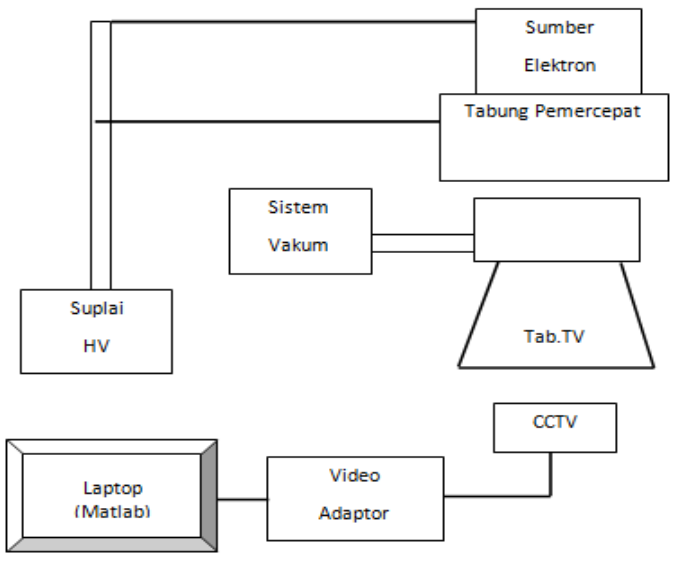

Gambar 6. Skema Modul Pengukuran Profil Berkas Elektron

\section{Perancangan Progam Akuisisi Data dan} Pengolahan Citra Berbasis GUI MATLAB

Terdapat empat tahapan submenu perancangan aplikasi:

\section{Akusisi Data Capture Video}

Tahapan capture video bertujuan untuk mendapatkan informasi citra digital dua dimensi dari hasil citra video dari tampilan profil berkas elektron pada layar tabung CRT secara langsung (real time) dengan memanfaatkan kamera jenis CCTV.

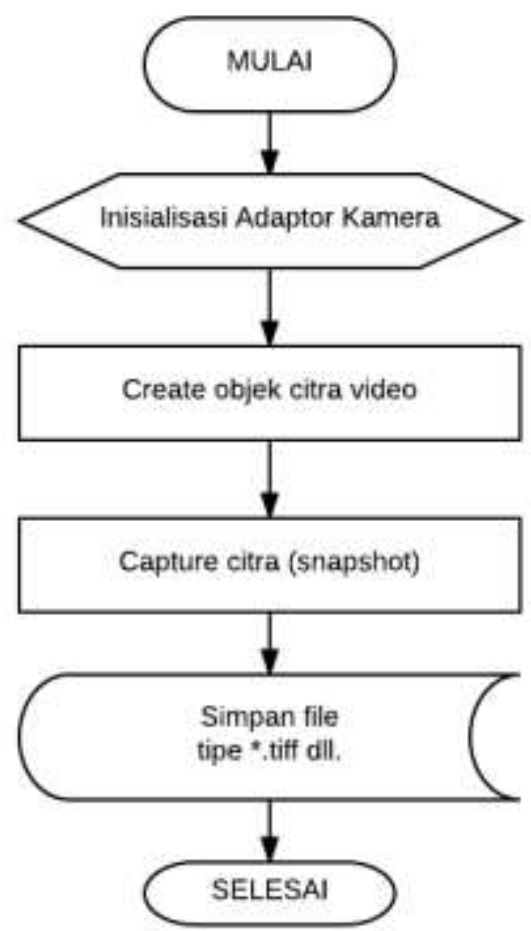

Gambar 7. Flowchart Akusisi Data Capture Video 


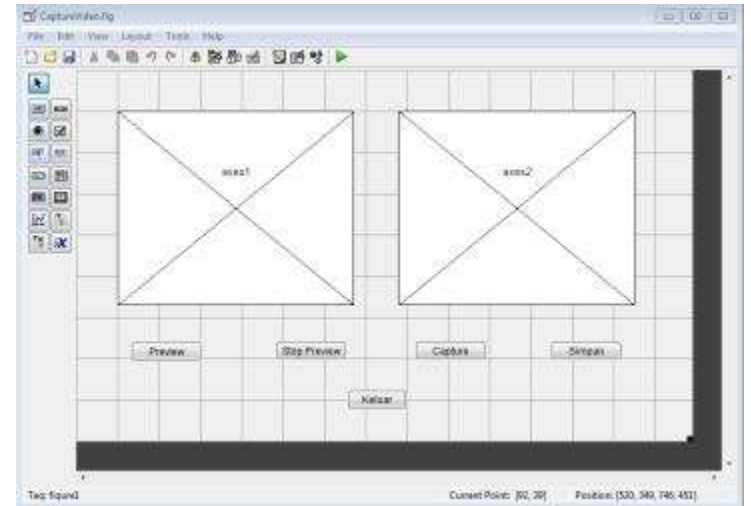

Gambar 8. Perancangan Tampilan GUI Capture Video

Perencanaan progam GUI capture video meliputi tahapan inisialisasi adaptor dari kamera untuk memperoleh informasi jenis adaptor kamera, resolusi kamera, format encoding warna, dan format video. Selanjutnya, citra video ditampilkan pada layar GUI dan dengan cara snapshot dihasilkan citra dua dimensi. Hasil capture disimpan pada drive folder yang dituju dengan file format *tiff. Pada Gambar 8 ditunjukkan perancangan tampilan GUI capture video.

\section{Preprocessing Citra}

Tahapan processing citra bertujuan untuk mengolah citra digital dua dimensi dari hasil citra capture video sehingga citra dapat diolah lebih lanjut dan mempermudah tahapan proses selanjutnya.

Tahapan preprocessing citra meliputi proses grayscale, cropping, contrast, dan noise filter dengan menggunakan teknik median filter. Hasilnya disimpan pada drive folder dengan file format .*tiff. Gambar 10 menunjukkan perancangan tampilan GUI preprocessing video.

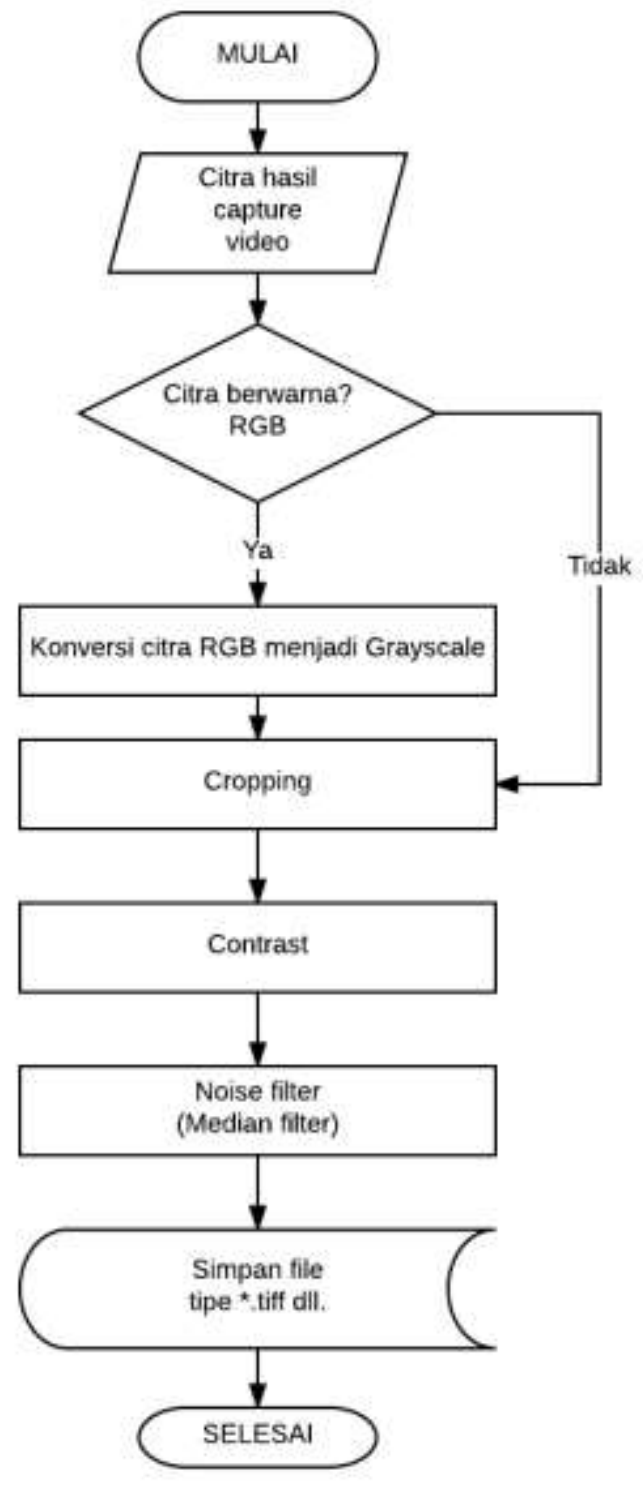

Gambar 9. Flowchart Preprocessing Citra

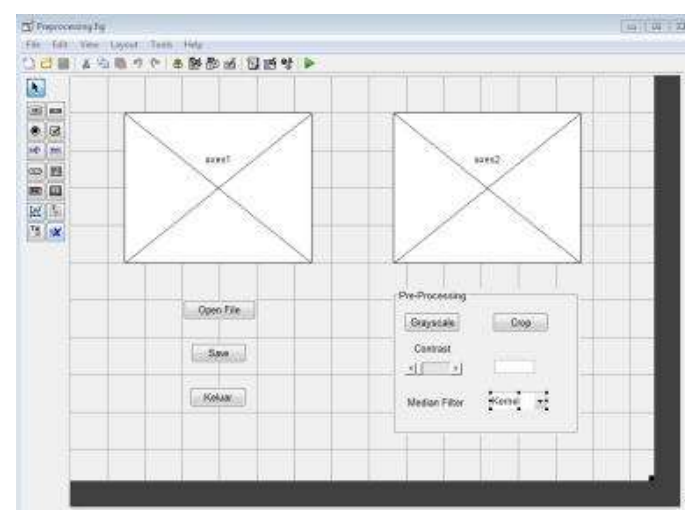

Gambar 10. Perancangan Tampilan GUI Preprocessing Citra 


\section{Segmentasi Citra}

Segmentasi merupakan tahapan penting untuk mendapatkan daerah (region) yang diinginkan sehingga mempermudah analisis dan identifikasi citra pada tahapan selanjutnya.

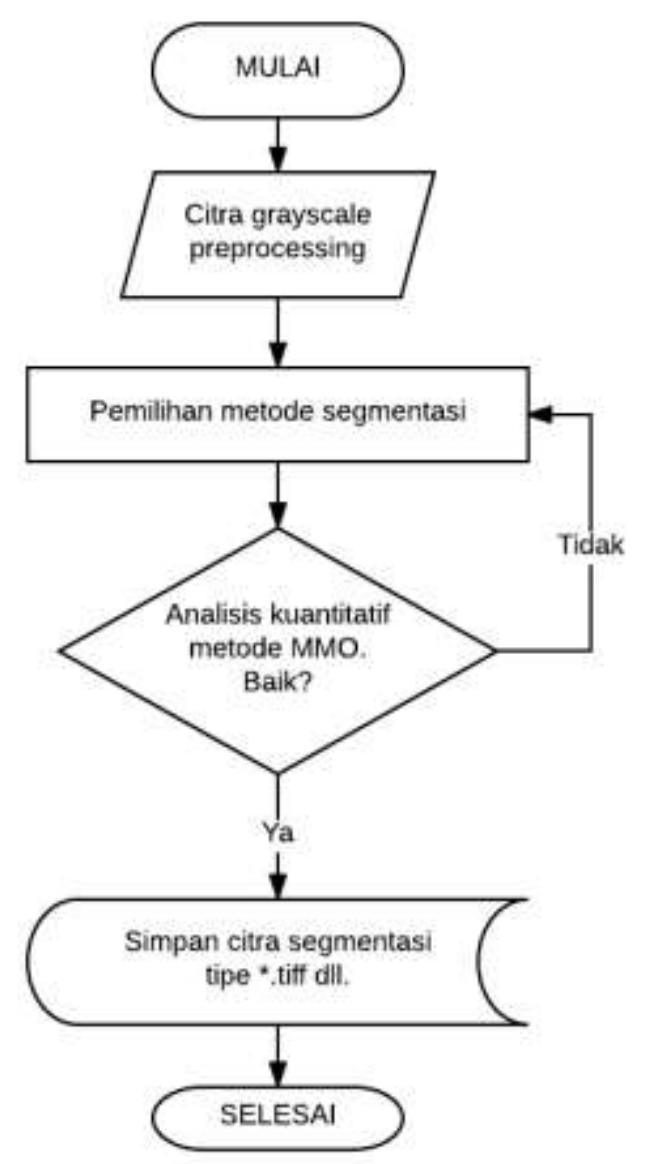

Gambar 11. Flowchart Segmentasi Citra

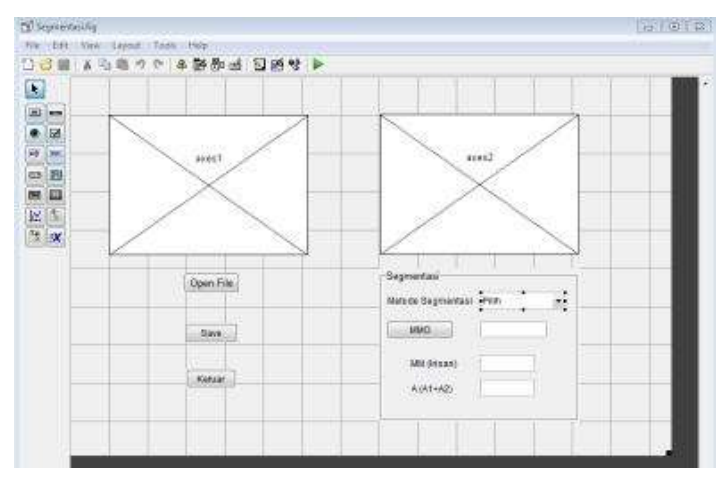

Gambar 12. Perancangan Tampilan GUI Segmentasi Citra

Teknik segmentasi yang digunakan meliputi thresholding, region growing, dan watershed. Analisis kuantitatif metode Metric
Mutual Overlap (MMO) digunakan untuk membandingkan ketiga teknik segmentasi agar diperoleh hasil yang terbaik mendekati 1 . Hasilnya disimpan pada drive folder dengan file format *tiff. Gambar 12 menunjukkan perancangan tampilan GUI 'segmentasi video'.

\section{Penentuan Profil Berkas Elektron}

Tahapan penentuan profil berkas elektron bertujuan memperoleh hasil sphericity atau tingkat kebulatan bentuk geometri citra dan plot distribusi intensitas dari citra profil berkas elektron.

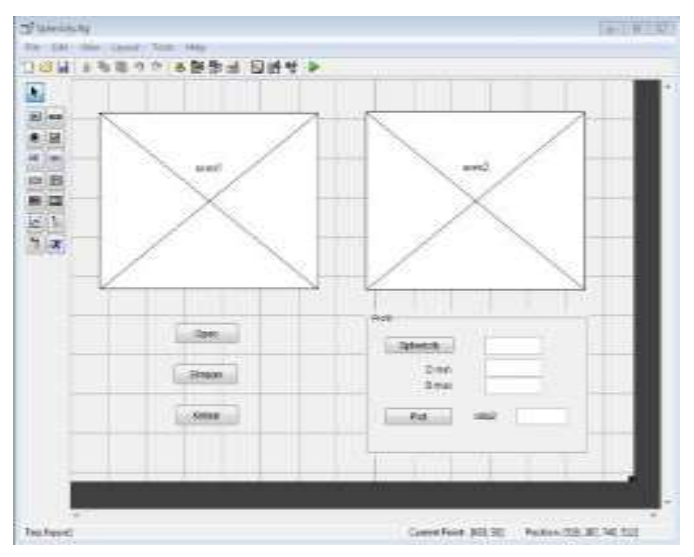

Gambar 13. Perancangan Tampilan GUI Penentuan Profil Berkas Elektron

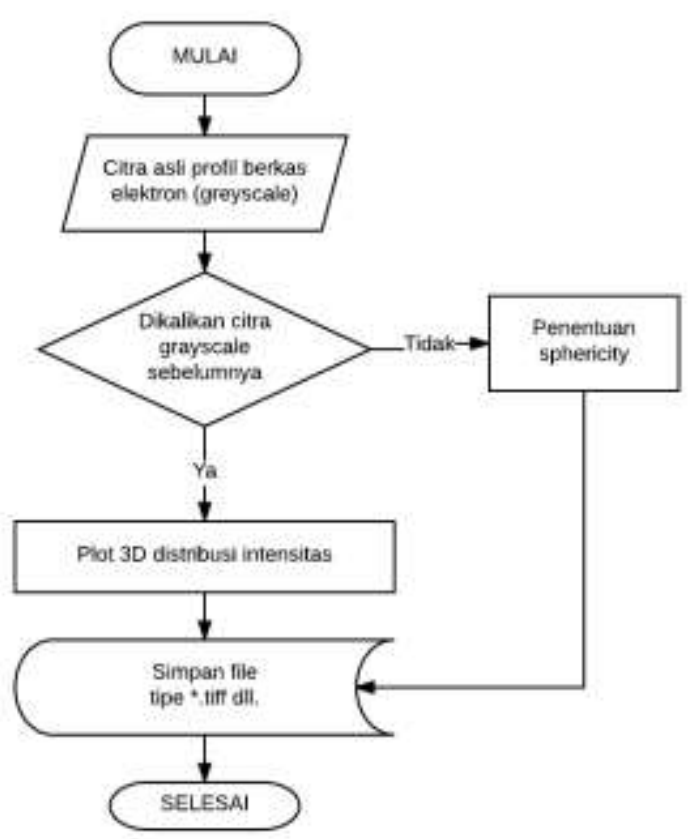

Gambar 14. Flowchart Penentuan Profil Berkas Elektron 
Penentuan nilai sphericity diperoleh dengan membandingkan nilai $\mathrm{D}_{\min }$ dan $\mathrm{D}_{\max }$, $\left(\mathrm{D}_{\min } / \mathrm{D}_{\max }\right)$ dari batasan region citra berkas elektron. Distribusi intensitas ditampilkan dalam grafik hasil plot 3D dengan metode surf dan hasil nilai rata-rata distribusi intensitasnya. Hasilnya disimpan pada drive folder dengan file format *tiff. Gambar 13, menunjukkan perancangan tampilan GUI penentuan profil berkas elektron.

\section{Karakterisasi Sumber Elektron Tipe Pierce (Dioda dan Trioda)}

Karakterisasi sumber elektron tipe Pierce (dioda dan trioda) dilakukan dengan cara menganalisis hasil luaran profil citra berkas elektron dari hasil pengaturan pada tiap-tiap parameter pengujian modul sumber elektron, yaitu meliputi arus filamen, tegangan pemfokus, dan tegangan pemercepat, dibandingkan dengan nilai hasil penentuan sphericity dan distribusi intensitasnya dari hasil plot kurva 3D dengan rata-rata intensitas dari citra uji dengan menggunakan progam GUI MATLAB yang telah dirancang pada penelitian ini.

\section{HASIL DAN PEMBAHASAN}

\section{Hasil Pengujian Aplikasi GUI MATLAB}

Tampilan menu utama berisi submenu aplikasi, yaitu capture video, preprocessing citra, segmentasi citra, dan penentuan profil berkas (sphericity dan plot distibusi intensitas), ditunjukkan pada Gambar 15.

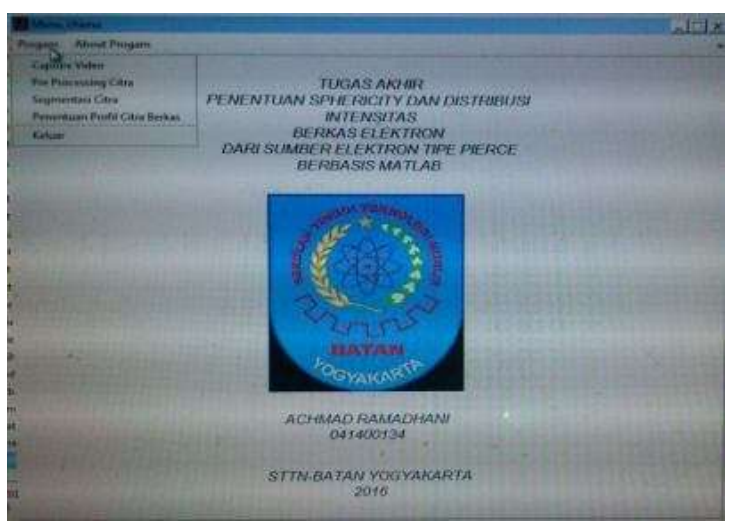

Gambar 15. Tampilan Menu Utama

\section{Submenu Capture Video}

Pada submenu capture video dilakukan pengambilan citra video berkas elektron kemudian di-snapshot menjadi citra dua dimensi, yang selanjutnya disimpan dengan format file *.tiff pada drive folder yang ditentukan.

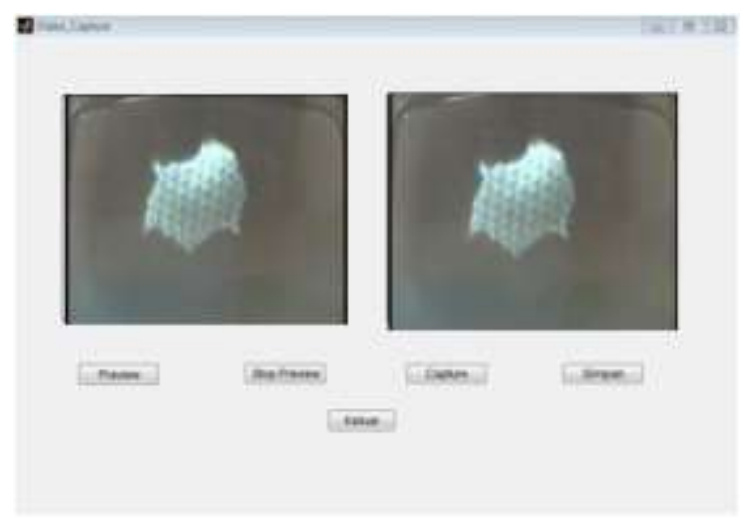

Gambar 16. Tampilan Submenu Capture Video

\section{Submenu Preprocessing Citra}

Pada submenu preprocessing citra dilakukan proses perbaikan kualitas citra berkas berwarna (RGB), yaitu meliputi proses grayscale, cropping, kontras, dan median filter.

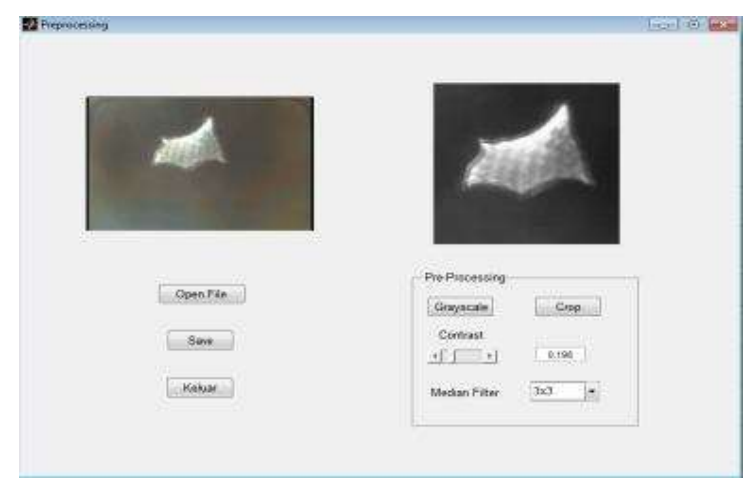

Gambar 17. Tampilan Submenu Preprocessing Citra

\section{Submenu Segmentasi Citra}

Pada submenu segmentasi citra dilakukan proses penentuan batasan region dari citra berkas elektron. Teknik segmentasi yang digunakan yaitu thresholding, region growing, dan watershed. Hasil segmentasi dibandingkan dengan citra ground truth dengan metode MMO (Mutual Metric Overlap). 


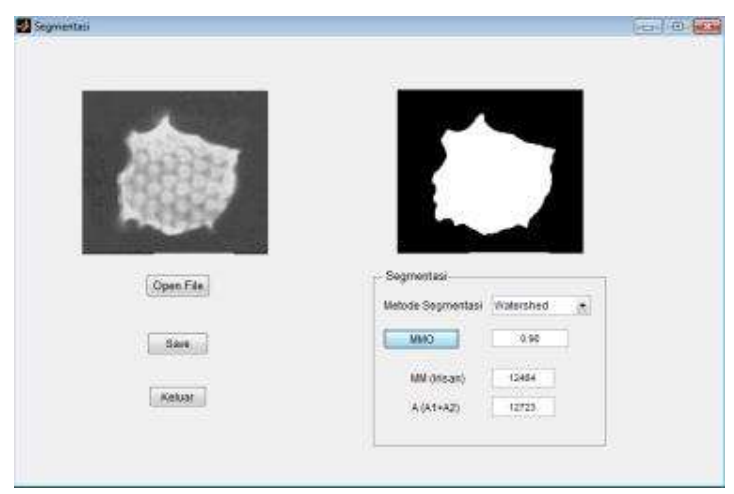

Gambar 18. Tampilan Submenu Segmentasi Citra

\section{Submenu Penentuan Profil Berkas}

Pada submenu penentuan profil berkas dilakukan penentuan nilai sphericity dengan perhitungan $\mathrm{D}_{\min } / \mathrm{D}_{\max }$ dan ditampilkan plot 3D dengan nilai rata-rata distribusi intensitas.

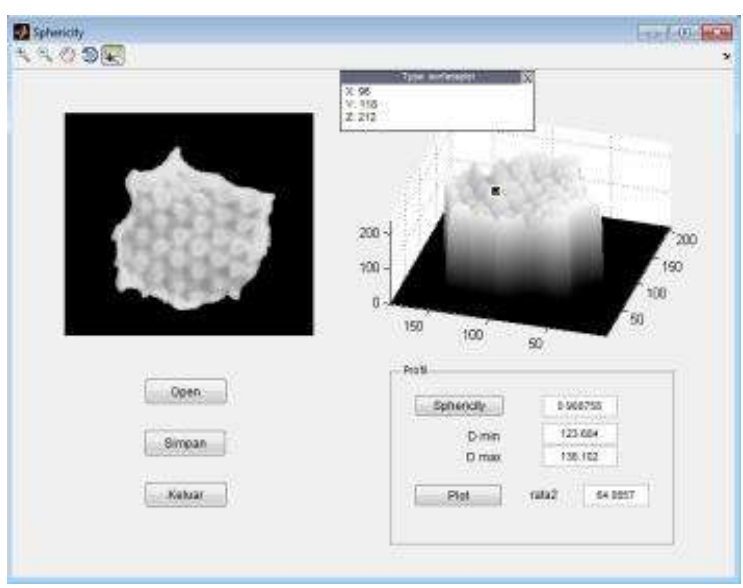

Gambar 19. Tampilan Submenu Penentuan Profil Berkas

\section{Hasil Penentuan Sphericity dan Plot 3D Distibusi Intensitas}

Pengujian progam untuk penentuan sphericity dan distribusi intensitas sebelumnya dilakukan validasi dengan file citra bola.png dan citra berkas.tiff.

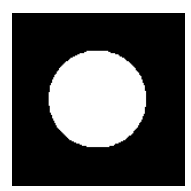

Gambar 20. Citra bola.png

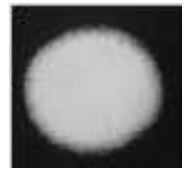

Gambar 21. Citra berkas.tiff
Diperoleh nilai sphericity 1 dan plot 3D distibusi intensitas memuncak di tengah dan merata, layaknya Gaussian, sebagaimana ditunjukkan pada Gambar 22.

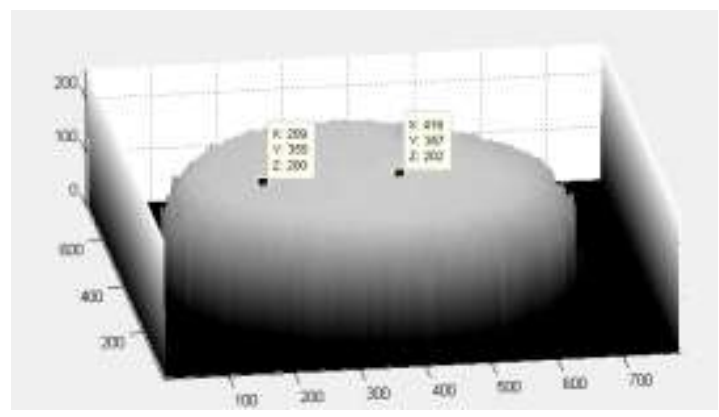

Gambar 22. Plot Grafik 3D Citra berkas.tiff

Dari hasil pengujian keseluruhan perancangan progam aplikasi untuk karakterisasi sumber elektron tipe Pierce (dioda dan trioda), diperoleh data pengujian sumber elektron dioda dan trioda pada tahun 2015 dan 2016 yang ditampilkan pada grafik, sebagaimana ditunjukkan pada Gambar 20 sampai dengan Gambar 25.

Pada Gambar 23 dan 24 ditunjukkan grafik hubungan perubahan parameter tegangan pemercepat dengan nilai sphericity dan nilai rata-rata intensitas antara dioda $v s$ trioda pada arus filamen ( $\mathrm{I}_{\text {Filamen }}$ ) 14 Ampere dan tegangan pemfokus $\left(\mathrm{V}_{\text {fokus }}\right) \quad 4,5 \mathrm{kVolt}$ tetap.

Dari Gambar 23 dan Gambar 24 dapat diperoleh jenis dioda dengan pengaturan tegangan pemercepat diperoleh sphericity cenderung stabil berkisar 0,6 . Nilai sphericity jenis trioda lebih baik dibandingkan dengan jenis dioda, sebanding dengan adanya kenaikan tegangan pemercepat, sedangkan nilai rata-rata distribusi intensitas pada jenis dioda lebih tinggi dibandingkan dengan jenis trioda. 


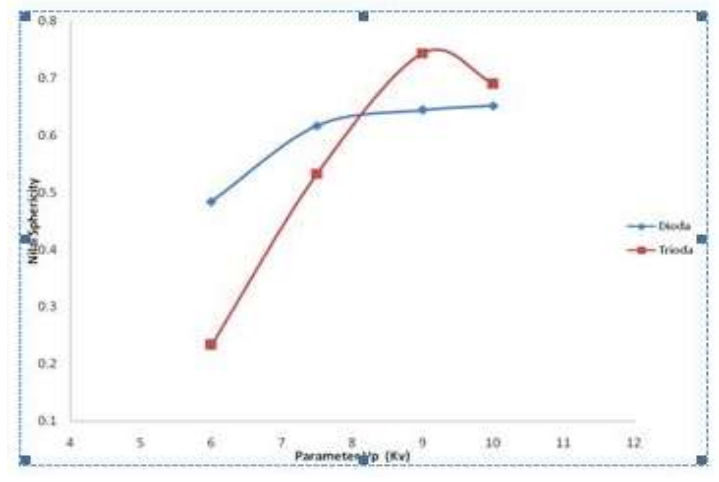

Gambar 23. Hubungan Parameter Tegangan Pemercepat (Vp) dengan Nilai Sphericity antara Dioda $v s$ Trioda pada Tahun 2016

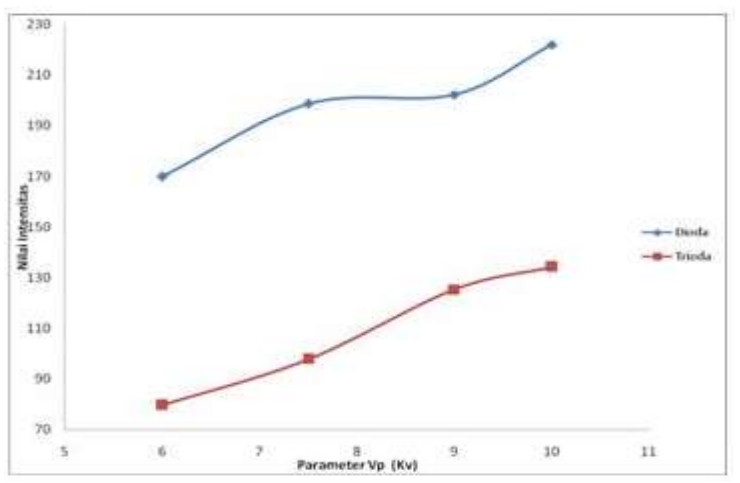

Gambar 24. Hubungan Parameter Tegangan Pemercepat (Vp) dengan Nilai Intensitas antara Dioda $v s$ Trioda pada Tahun 2016

Pada Gambar 25 dan 26 ditunjukkan grafik hubungan perubahan parameter tegangan pemercepat dengan nilai sphericity dan nilai rata-rata intensitas antara dioda vs trioda pada arus filamen $\left(\mathrm{I}_{\text {Filamen }}\right) 14$ Ampere dan tegangan pemfokus $\left(\mathrm{V}_{\text {fokus }}\right) 9 \mathrm{kVolt}$ tetap.

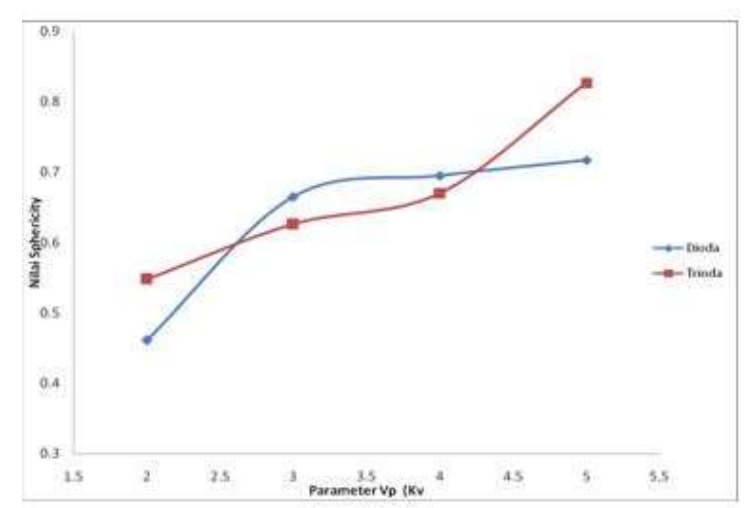

Gambar 25. Hubungan Parameter Tegangan Pemercepat (Vp) dengan Nilai Sphericity antara Dioda $v s$ Trioda pada Tahun 2015

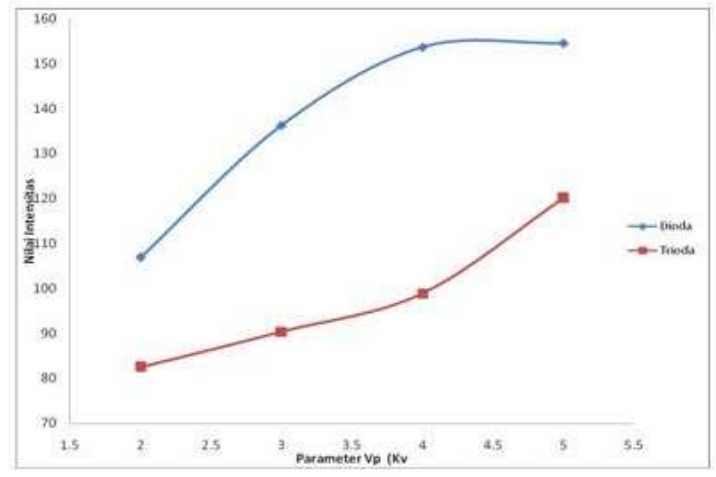

Gambar 26. Hubungan Parameter Tegangan Pemercepat (Vp) Dengan Nilai Intensitas antara Dioda $v s$ Trioda pada Tahun 2015

Dari Gambar 25 dan Gambar 26 dapat diperoleh informasi bahwa jenis dioda dengan pengaturan tegangan pemercepat diperoleh sphericity cenderung stabil berkisar 0,6 . Nilai rata-rata distribusi intensitas pada jenis dioda dan trioda sebanding dengan perubahan tegangan pemercepat. Nilai sphericity jenis trioda lebih baik dibandingkan dengan jenis dioda, sebanding dengan adanya kenaikan tegangan pemercepat Nilai rata-rata distribusi intensitas pada jenis dioda lebih tinggi dibandingkan dengan jenis trioda.

Pada Gambar 27 dan 28 ditunjukkan grafik perubahan parameter tegangan pemfokus dengan nilai sphericity dan nilai rata-rata intensitas jenis sumber elekton trioda pada arus filamen ( $\left.\mathrm{I}_{\text {Filamen }}\right) 14$ ampere dan tegangan pemercepat $(\mathrm{Vp}) 10 \mathrm{kVolt}$ tetap.

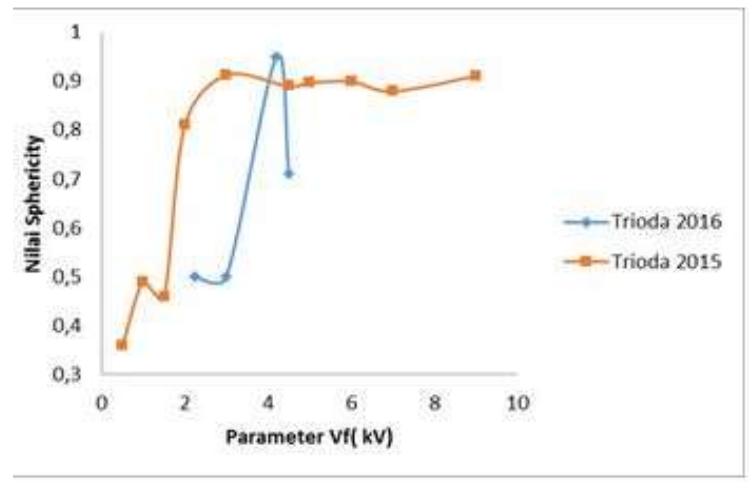

Gambar 27. Hubungan Parameter Nilai Tegangan Pemfokus $\left(\mathrm{V}_{\mathrm{f}}\right)$ dengan Nilai Sphericity antara Trioda Tahun 2015 vs Trioda Tahun 2016 


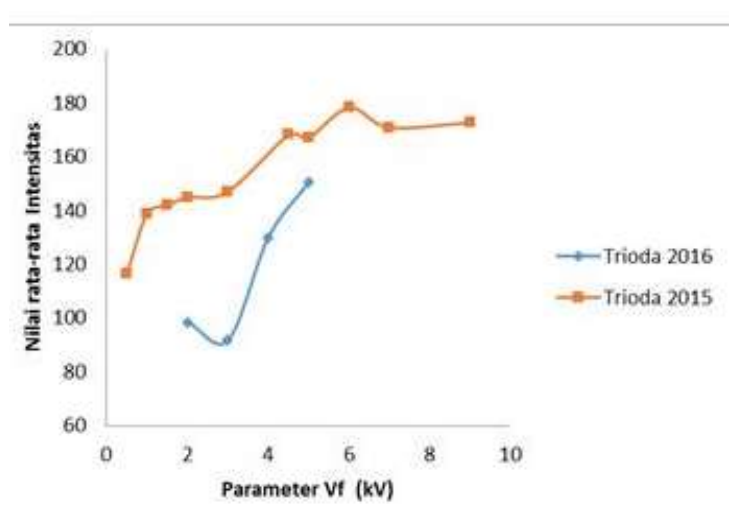

Gambar 28. Hubungan Parameter Nilai Tegangan Pemfokus $\left(\mathrm{V}_{\mathrm{f}}\right)$ dengan Nilai Intensitas antara Trioda Tahun 2015 vs Trioda Tahun 2016

Dari Gambar 27 dan 28 diperoleh informasi bahwa pada pengujian trioda tahun 2015 diperoleh hasil sphericity lebih baik dan cenderung stabil pada kisaran nilai 0,9 dibandingkan dengan pengujian trioda pada tahun 2106. Nilai rata-rata distibusi intensitas jenis trioda pada tahun 2015 lebih tinggi dibandingkan tahun 2016.

Gambar 29 sampai Gambar 31 memperlihatkan plot grafik 3D distribusi intensitas yang menunjukkan perubahan sphericity yang lebih baik dengan nilai distribusi intensitas yang lebih merata dengan adanya perubahan tegangan pemfokus pada pengujian tahun 2016

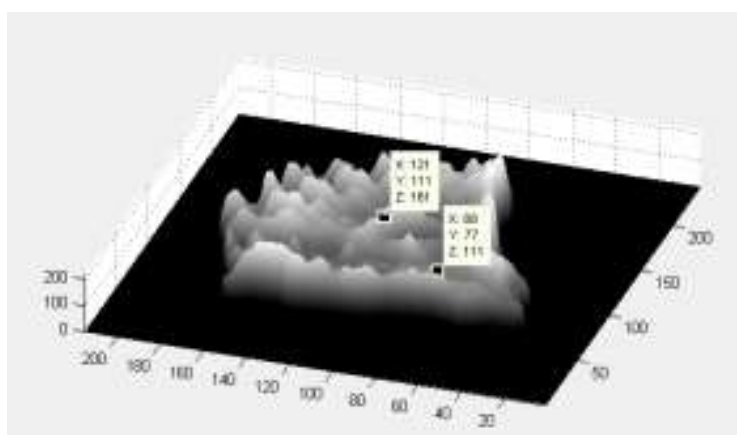

Gambar 29. Plot Grafik 3D dari Citra Trioda pada $\mathrm{V}_{\mathrm{f}}=0,5 \mathrm{kV}, \mathrm{V}_{\mathrm{f}}=10 \mathrm{kV}$, dan $\mathrm{I}_{\mathrm{F}}=14 \mathrm{~A}$, Datasheet

Tahun 2016

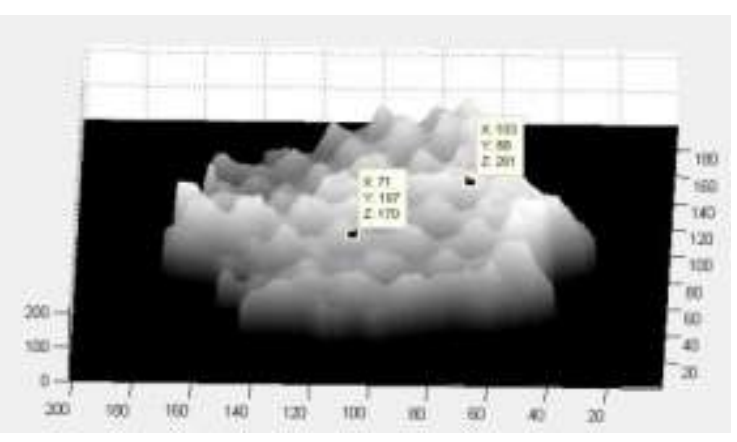

Gambar 30. Plot Grafik 3D dari Citra Trioda pada $\mathrm{V}_{\mathrm{f}}=3 \mathrm{kV}, \mathrm{V}_{\mathrm{p}}=10 \mathrm{kV}$, dan $\mathrm{I}_{\mathrm{F}}=14 \mathrm{~A}$, Datasheet Tahun 2016

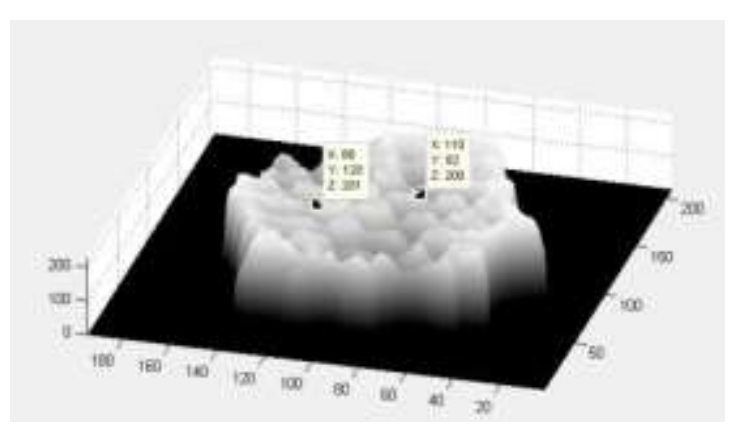

Gambar 31. Plot Grafik 3D dari Citra Trioda pada $\mathrm{V}_{\mathrm{f}}=9 \mathrm{kV}, \mathrm{V}_{\mathrm{p}}=10 \mathrm{kV}$, dan $\mathrm{I}_{\mathrm{F}}=14 \mathrm{~A}$, Datasheet

Tahun 2016

\section{KESIMPULAN DAN SARAN}

\section{Kesimpulan}

1. Telah berhasil dirancang aplikasi progam GUI berbasis MATLAB untuk karakterisasi sumber elektron (dioda dan trioda) dengan aplikasi yang memiliki empat tahapan, yaitu capture video, preprocessing citra, segmentasi, dan penentuan profil berkas untuk mendapatkan sphericity dan plot grafik 3D dengan nilai rata-rata distribusi intensitas.

2. Dengan teknik segmentasi watershed pada perhitungan MMO (Metric Mutual Overlap) diperoleh nilai persentase terbaik secara kuantitatif dibandingkan dengan teknik segmentasi threshold dan region growing.

3. Parameter perubahan tegangan pemercepat dan tegangan pemfokus pada arus filamen tetap berpengaruh terhadap nilai sphericity dan nilai rata-rata distribusi intensitas pada sumber elektron jenis dioda dan trioda. Jenis dioda memiliki nilai rata-rata intensitas lebih tinggi dengan distribusi 
intensitas tidak merata dibandingkan dengan jenis trioda, sedangkan jenis trioda memiliki nilai sphericity lebih baik dengan nilai rata-rata distibusi intensitas merata dibandingkan jenis dioda.

\section{Saran}

1. Perlu dikembangkan lagi pemilihan teknik segmentasi yang lebih baik untuk mendapatkan batasan citra berkas elektron yang mendekati batasan visual mata manusia.

2. Perlu dikembangkan embedded system, yang meliputi kesatuan perangkat hardware dan software yang mampu mengolah dan memproses berkas elektron yang menampilkan nilai sphericity dan plot distibusi intensitas secara langsung dan dapat dipakai secara portable oleh user sehingga memiliki nilai jual untuk dikomersilkan.

3. Alternatif software lain yang berbasis open source bisa menjadi pilihan untuk pengembangan pemrogaman pengolahan citra digital.

4. Perlu dikembangkan perancangan progam GUI MATLAB secara otomatis untuk mengolah input data citra berkas sehingga diperoleh hasil sphericity dan distribusi intensitas secara langsung tanpa memakan waktu pemrosesan dan meminimalisir keterlibatan user sebagai operator.

\section{DAFTAR PUSTAKA}

1. Suprapto, Djoko SP., Djasiman. 2007. Karakterisasi Sumber Elektron MBE Untuk Industri Lateks. Laporan Teknis di PTAPB-BATAN,Yogyakarta

2. Suprapto, Djoko SP., Djasiman. 2001. Rekonstruksi Sumber Elektron Termionik Dengan Elektrode Pierce Untuk MBE 500 $\mathrm{keV} / 10 \mathrm{~mA}$. Prosiding Pertemuan dan Presentasi Ilmiah, Penelitian Dasar Ilmu Pengetahuan dan Teknologi Nuklir P3TM-BATAN, Yogyakarta.

3. Darsono, Suhartono, Elin N, dan Sutadi. 2013. Optimasi Operasi Sistem Pemayar MNE Lateks $300 \mathrm{keV} / 20 \mathrm{~mA}$. Prosiding Pertemuan dan Presentasi Ilmiah Teknologi Akselerator dan Aplikasinya PTAPB-BATAN, Yogyakarta.

4. Suhartono. 2002. Karakterisasi Sumber Elektron Termionik Model Elektrode
Pierce pada Mesin Berkas Elektron (MBE) P3TM. Jurusan Teknik Fisika Nuklir STTN-BATAN, Yogyakarta.

5. Darsono, Suhartono, Suprapto, dan Elin N. 2015. Pengukuran Bentuk Profil Berkas Elektron Tipe Pierce Menggunakan Sensor Tabung TV. Prosiding Pertemuan dan Presentasi Ilmiah, Penelitian Dasar Ilmu Pengetahuan dan Teknologi Nuklir PSTA-BATAN, Yogyakarta.

6. Suprapto. 2004. Pengembangan Rancangbangun Sumber Elektron untuk Mesin Berkas Elektron $350 \mathrm{keV} / 10 \mathrm{~mA}$ P3TM-BATAN. Laporan Presentasi Ilmiah P3TM-BATAN, Yogyakarta.

7. Tatik Yuniati, Copyright @2008-2014 ilmuti.org

8. Wijaya, Marvin Ch. Dan Prijono, Agus. 2007. Pengolahan Citra Digital Menggunakan MATLAB. Bandung: Informatika Bandung.

9. Siahaan, Meilinda. 2009. Implementasi Segmentasi Citra Menggunakan Metode Graph yang Efesien. Departemen Matematika, Fakultas Matematika dan Ilmu Pengetahuan Alam, Universitas Sumatera Utara.

10. Milan Sonka, Vaclav Hlavac, and Roger Bayle. 2008. Image Processing, Analysis, and Machine Vision. United States of America: Thomson.

11. Kharina Ns, D. Andiwijayakusuma. 2012. Komputasi Sphericity Berbasis Image Processing Pada Kernel Bahan Bakar HTGR. Lokakarya Komputasi dalam Sains dan Teknologi Nuklir, Pusat Pengembangan Informatika Nuklir BATAN, Serpong. 